\title{
KINERJA KALIUM METAVANADAT SEBAGAI INHIBITOR KOROSI BAJA KARBON RENDAH DALAM LINGKUNGAN KLORIDA DAN SULFIDA
}

\author{
Isdiriayani N., R. Asri Pratiwi, Aditya Farhan A., Fikri Anggara P., Rennie Sari \\ Program Studi Teknik Kimia, Fakultas Teknologi Industri, Institut Teknologi Bandung \\ Gd. Labtek X, Jl. Ganesha 10 Bandung 40132 \\ E-mail: isdi@che.itb.ac.id
}

\begin{abstract}
Abstrak
Penambahan inhibitor merupakan salah satu metode pengendalian korosi. Kalium metavanadat $\left(\mathrm{KVO}_{3}\right)$ sering digunakan sebagai inhibitor korosi pada absorber $\mathrm{CO}_{2}$ yang menggunakan larutan Benfield. Hasil penelitian sebelumnya menunjukkan bahwa $\mathrm{KVO}_{3}$ mampu menginhibisi korosi baja karbon rendah dalam air laut yang mengandung bakteri pereduksi sulfat (SRB) dengan bertindak sebagai biosida. Klorida dan sulfida merupakan ion-ion korosif yang umum ditemui dalam fluida proses di industri. Penelitian ini dilakukan untuk mempelajari kinerja $\mathrm{KVO}_{3}$ sebagai inhibitor korosi baja karbon rendah dalam lingkungan akuatik yang terkontaminasi klorida, ataupun sulfida. Untuk mencapai tujuan tersebut dilakukan pengukuran laju korosi baja karbon rendah dengan jenis dan konsentrasi kontaminan bervariasi. Pengukuran laju korosi dilakukan dengan metode Tafel. Mekanisme inhibisi diprediksi dengan metode voltametri siklik. Sedangkan produk korosi diidentifikasi dengan menggunakan spektrometri difraksi sinar X (XRD). Dari penelitian ini, diperoleh hasil bahwa $\mathrm{KVO}_{3}$ efektif sebagai inhibitor korosi baja karbon rendah pada lingkungan klorida berkonsentrasi antara $20 \mathrm{~g} / \mathrm{L}$ hingga $30 \mathrm{~g} / \mathrm{L}$ dengan efisiensi di atas 99\%. Pada lingkungan sulfida, $\mathrm{KVO}_{3}$ kurang efektif menginhibisi korosi baja karbon rendah. Sedangkan pada air laut sintetik yang mengandung sulfida, walaupun belum termasuk kategori inhibitor efektif, namun $\mathrm{KVO}_{3}$ dapat menurunkan laju korosi baja karbon dengan efisiensi inhibisi yang meningkat seiring dengan kenaikan konsentrasi sulfida.
\end{abstract}

Kata kunci: kalium metavanadat, baja karbon rendah, inhibitor korosi

\begin{abstract}
Inhibitor addition is one of the common corrosion control methods. Potassium metavanadate $\left(\mathrm{KVO}_{3}\right)$ is the common corrosion inhibitor for Benfield solution in $\mathrm{CO}_{2}$ absorber. Former research shows that $\mathrm{KVO}_{3}$ is also able to inhibit the corrosion in seawater containing Sulphate Reducing Bacteria (SRB) due to its capacity as biocide. Chloride and Sulfide are common corrosive ions found in process fluids in industries. Therefore, this research is carried out to study the performance of $\mathrm{KVO}_{3}$ as a corrosion inhibitor for low- carbon steel in chloride and sulfide contaminated environment. The objective of this research was achieved by measuring low-carbon steel corrosion rate in various concentrations of contaminants. The corrosion rate was measured by Tafel method. The corrosion inhibition mechanisms were studied using cyclic voltammetry method. Meanwhile the corrosion products were identified by $X$ - ray diffraction spectrometry $(X R D)$. This research results that $\mathrm{KVO}_{3}$ is an effective corrosion inhibitor in chloride environment when the chloride concentration ranges between $20 \mathrm{~g} / \mathrm{L}$ and $30 \mathrm{~g} / \mathrm{L}$. In this range of concentration, $\mathrm{KVO}_{3}$ performs more than $99 \%$ efficiency. While in sulfide environment, $\mathrm{KVO}_{3}$ is an ineffective corrosion inhibitor. On the other hand, the addition of KVO3 reduces the corrosion rate of carbon steel in seawater containing sulfide, although its performance does not meet the effective inhibitor criteria. Higher concentration of sulfide results the higher inhibition efficiency of KVO3.
\end{abstract}

Keywords: Potassium metavanadate, low - carbon steel, corrosion inhibitor 


\section{Pendahuluan}

Korosi adalah kerusakan material yang disebabkan reaksi antara material tersebut dengan lingkungannya. Korosi dapat menimbulkan kerusakan pada peralatan proses sehingga mengganggu jalannya proses. Dengan demikian korosi dianggap merugikan karena menyebabkan kehilangan produk yang berharga dan meningkatkan biaya perawatan serta perbaikan atau penggantian alat. Oleh sebab itu, korosi harus dicegah atau dikendalikan.

Salah satu cara untuk mengendalikan korosi pada baja karbon rendah adalah dengan menggunakan inhibitor korosi, yaitu zat yang bila ditambahkan dalam jumlah sedikit pada lingkungan korosif, mampu mengurangi laju reaksi korosi. Salah satu inhibitor yang sering digunakan adalah kalium metavanadat $\left(\mathrm{KVO}_{3}\right)$ yang biasa digunakan sebagai inhibitor korosi pada lingkungan karbonat-bikarbonat dalam absorber $\mathrm{CO}_{2}$.

Lingkungan klorida umum dijumpai pada industri kimia sebagai lingkungan korosif, seperti air laut yang digunakan sebagai air pendingin. Korosivitas air laut tergantung pada keberadaan oksigen terlarut, salinitas, ion-ion minor, aktivitas biologis dan polutan. Salah satu polutan yang dianggap korosif adalah senyawa sulfida.

Hasil penelitian Hanifah dan Fang Ping (2006) menunjukan bahwa $\mathrm{KVO}_{3}$ mampu menurunkan laju korosi baja di dalam air laut yang mengandung bakteri pereduksi sulfat (SRB). Penelitian tersebut hanya menunjukkan kerja $\mathrm{KVO}_{3}$ sebagai biocide namun belum menyatakan kerja $\mathrm{KVO}_{3}$ sebagai inhibitor korosi. Oleh karena itu penelitian ini bertujuan untuk mempelajari kinerja $\mathrm{KVO}_{3}$ sebagai inhibitor korosi baja dalam lingkungan klorida dan air laut yang mengandung sulfida tetapi bukan metabolit bakteri.

Penelitian ini dilakukan dengan pengukuran laju korosi baja dalam lingkungan klorida dan sulfida menggunakan metode Tafel, serta prediksi mekanisme korosi menggunakan metode voltametri siklik. Analisis kimia produk korosi dilakukan dengan menggunakan spektrometri difraksi sinar X.

\section{Fundamental}

Secara elektrokimia, korosi baja karbon di lingkungan akuatik mengandung oksigen terlarut melibatkan reaksi-reaksi

oksidasi logam:

$\mathrm{Fe} \rightarrow \mathrm{Fe}^{2+}+2 \mathrm{e}^{-}$

dan reduksi:

$\mathrm{O}_{2}+2 \mathrm{H}_{2} \mathrm{O}+4 \mathrm{e}^{-} \rightarrow 4 \mathrm{OH}^{-}$
Baja karbon merupakan logam yang mampu pasif. Pasivasi adalah hilangnya reaktivitas kimia dari logam akibat pembentukan lapisan oksida pelindung di permukaan logam. Contoh reaksi pembentukan lapisan pasif:

$\mathrm{Fe}^{2+}+\mathrm{O}_{2}+\mathrm{H}_{2} \mathrm{O} \rightarrow \mathrm{Fe}(\mathrm{OH})_{3}$

$\mathrm{KVO}_{3}$ merupakan inhibitor anodik tetapi tidak bersifat oksidator (Rozenfeld, 1981). $\mathrm{KVO}_{3}$ dapat memperkuat pembentukan lapisan pasif di permukaan baja dengan mengikat ion $\mathrm{Fe}^{3+}$ menjadi $\mathrm{FeVO}_{4}$ yang mengendap di permukaan baja (Williams and Leckie, 1968).

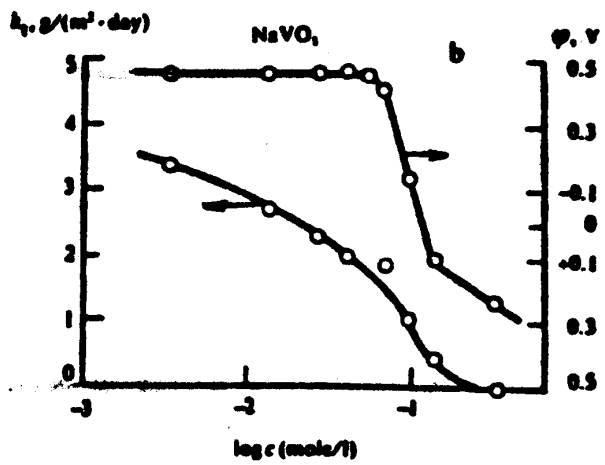

Gambar 1. Pengaruh penambahan inhibitor $\mathrm{KVO}_{3}$ terhadap laju korosi dan potensial baja karbon dalam larutan $\mathrm{Na}_{2} \mathrm{SO}_{4}$ (Rozenfeld,1981)

Perilaku elektrokimia sistem secara lengkap dapat dipelajari dengan memvariasikan potensial sistem dan mencatat perubahan arus yang timbul terhadap waktu. Teknik pengukuran dengan variasi potensial terhadap waktu disebut teknik polarisasi. Polarisasi dengan pemindaian potensial dalam arah bolakbalik disebut polarisasi siklik atau lebih dikenal sebagai Voltametri Siklik. Hasil pengukuran Voltametri Siklik berupa kurva hubungan arus terhadap potensial.

Aluran potensial terhadap arus menghasilkan arus puncak katodik dan anodik. Arus pada pemindaian balik yang lebih rendah dari pemindaian maju untuk potensial yang sama mengindikasikan terjadinya pasivasi. Apabila yang terjadi sebaliknya, maka hal tersebut mengindikasikan percepatan korosi karena bertambahnya luas permukaan aktif sebagai akibat dari pelarutan atom-atom logam di permukaan.

Jumlah puncak anodik dan katodik mengindikasikan jumlah tahap reaksi elektrokimia. Jarak antara potensial puncak anodik $\left(\mathrm{E}_{\mathrm{pa}}\right)$ dan katodik $\left(\mathrm{E}_{\mathrm{pc}}\right)$ merupakan indikator reversibilitas reaksi. Reaksi disebut reversibel jika $\left(\mathrm{E}_{\mathrm{pa}}-\mathrm{E}_{\mathrm{pc}}\right)$ mendekati 0,059/n V. Perbandingan intensitas arus puncak katodik dan anodik merupakan indikator kestabilan produk korosi. Produk reaksi elektrokimia 
dikatakan stabil (tidak langsung berubah menjadi senyawa lain), jika perbandingan intensitas arus puncak anodik dan katodik mendekati 1.

Voltametri Siklik (Bard, 2001)

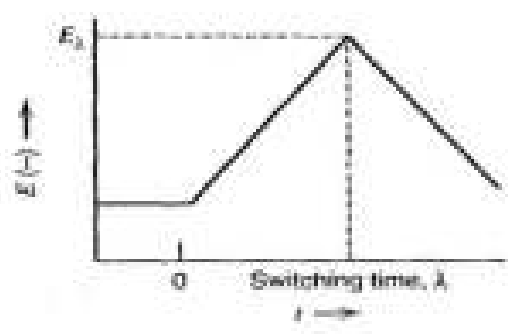

(a)

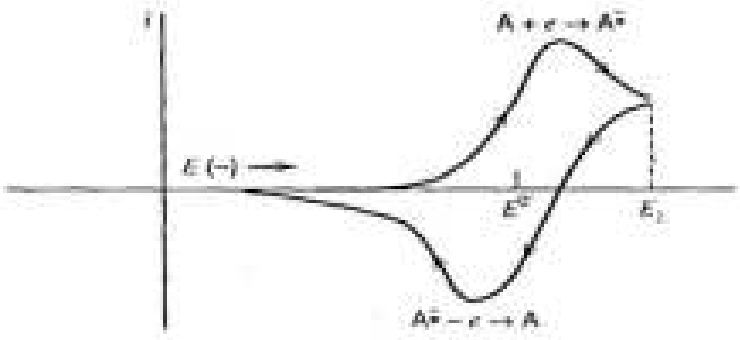

$(b)$

Gambar 2. (a) Grafik perubahan potensial siklik (b) hasil voltamogram siklik (Bard, 2001)

\section{Metodologi}

Spesimen yang digunakan pada penelitian ini adalah pelat baja karbon rendah tipe AISI 1010 berukuran $1 \mathrm{~cm} \times 1 \mathrm{~cm}$ dengan ketebalan $2 \mathrm{~mm}$ yang diabrasi dengan kertas abrasif hingga grid 1200. Komposisi kimia baja karbon rendah tersebut ditampilkan pada Tabel 1 .

Tabel 1. Komposisi spesimen baja karbon rendah

\begin{tabular}{|l|l|}
\hline Unsur & \% berat \\
\hline $\mathrm{C}$ & 0.13 \\
\hline $\mathrm{Si}$ & 0.078 \\
\hline $\mathrm{P}$ & 0.018 \\
\hline $\mathrm{S}$ & 0.006 \\
\hline $\mathrm{Mn}$ & 0.321 \\
\hline $\mathrm{Cu}$ & 0.414 \\
\hline $\mathrm{Fe}$ & balance \\
\hline
\end{tabular}

Percobaan dilakukan pada temperatur dan tekanan ruang tanpa pengadukan (laju pengadukan $=$ nol). Variasi komposisi larutan ditampilkan pada Tabel 2 dan Tabel 3.

Tabel 2. Variasi konsentrasi larutan

\begin{tabular}{|c|c|c|}
\hline Pengotor & Konsentrasi & {$\left[\mathrm{KVO}_{3}\right]$} \\
\hline \multirow{6}{*}{$\mathrm{NaCl}$} & \multirow{2}{*}{$20 \mathrm{~g} / \mathrm{L}$} & 0 \\
\hline & & $80 \mathrm{mg} / \mathrm{L}$ \\
\hline & \multirow{2}{*}{$30 \mathrm{~g} / \mathrm{L}$} & 0 \\
\hline & & $80 \mathrm{mg} / \mathrm{L}$ \\
\hline & \multirow{2}{*}{$40 \mathrm{~g} / \mathrm{L}$} & 0 \\
\hline & & $80 \mathrm{mg} / \mathrm{L}$ \\
\hline \multirow{6}{*}{$\mathrm{Na}_{2} \mathrm{~S}$} & \multirow{2}{*}{$200 \mathrm{mg} / \mathrm{L}$} & 0 \\
\hline & & $80 \mathrm{mg} / \mathrm{L}$ \\
\hline & \multirow{2}{*}{$300 \mathrm{mg} / \mathrm{L}$} & 0 \\
\hline & & $80 \mathrm{mg} / \mathrm{L}$ \\
\hline & \multirow{2}{*}{$400 \mathrm{mg} / \mathrm{L}$} & 0 \\
\hline & & $80 \mathrm{mg} / \mathrm{L}$ \\
\hline
\end{tabular}

Tabel 3. Variasi komposisi larutan uji menggunakan air laut sintetik

\begin{tabular}{|c|c|c|c|}
\hline No & Larutan & {$\left[\mathrm{S}^{2-}\right] \mathrm{ppm}$} & {$\left[\mathrm{KVO}_{3}\right] \mathrm{ppm}$} \\
\hline 1 & \multirow{16}{*}{$\begin{array}{l}\text { Air Laut } \\
\text { Sintetik }\end{array}$} & 0 & 0 \\
\hline 2 & & 150 & 0 \\
\hline 3 & & 200 & 0 \\
\hline 4 & & 250 & 0 \\
\hline 5 & & 0 & 20 \\
\hline 6 & & 150 & 20 \\
\hline 7 & & 200 & 20 \\
\hline 8 & & 250 & 20 \\
\hline 9 & & 0 & 40 \\
\hline 10 & & 150 & 40 \\
\hline 11 & & 200 & 40 \\
\hline 12 & & 250 & 40 \\
\hline 13 & & 0 & 80 \\
\hline 14 & & 150 & 80 \\
\hline 15 & & 200 & 80 \\
\hline 16 & & 250 & 80 \\
\hline
\end{tabular}

Skema rangkaian alat yang digunakan untuk uji polarisasi ditunjukkan pada Gambar 3.

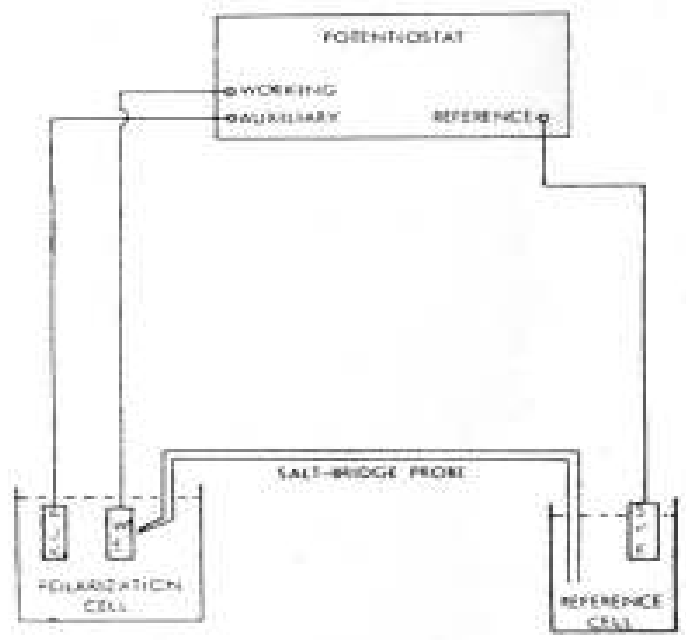

Gambar 3. Skema rangkaian alat 